\title{
The influence of acetylation status of tuberculosis patients on the isoniazid serum concentrations and sputum conversion after intensive phase therapy
}

\author{
Dwi Indria Anggraini ${ }^{1 *}$, Erna Kristin ${ }^{2}$, Iwan Dwiprahasto ${ }^{2}$ \\ ${ }^{1}$ Department of Pharmacology, Faculty of Medicine, Lampung University, Tanjung Karang, \\ ${ }^{2}$ Department of Pharmacology and Therapy, Faculty of Medicine, Universitas Gadjah \\ Mada, Yogyakarta, Indonesia
}

DOI: http://dx.doi.org/10.19106/JMedSci005001201807

\section{ABSTRACT}

Isoniazid (INH), one of the major antituberculosis drugs, is metabolized by acetylation. Previously study proved the significant differences of serum INH concentration between subject with fast and slow acetylation status. However, the correlation of acetylation status with treatment outcome after fixed-dose combination antituberculosis therapy (FDC-ATT) was not explained. The aim of this study was to evaluate the influence of acetylation status on the treatment outcome and the serum INH concentrations in the adult tuberculosis patients underwent FDC-ATT. A cross sectional study was carried out on 31 tuberculosis patients. Acetylation status was measured by spectrophotometer and serum INH concentration was measured by high performance liquid chromatography (HPLC). Sputum conversion assay was conducted by Ziehl Nelsen method. t-Test, chi square, Mann-Whitney, and Fisherman were used to analyze the data. The proportion of the fast acetylator was $61.3 \%$, whereas the slow acetylator was $38.7 \%$. The proportion of success and failure sputum conversion were $83.9 \%$ and $16.1 \%$, respectively. The mean serum INH concentration in the fast acetylator groups $(1.52 \pm 0.15 \mu \mathrm{g} / \mathrm{mL})$ was significantly lower than that in the slow acetylator groups $(3.84 \pm 0.35 \mu \mathrm{g} / \mathrm{mL})$. The failure conversion risk of the fast acetylator group was about two folds higher than the slow acetylator group, although it was not significantly different $\quad(R R=2.53 ; 95 \%$ $\mathrm{Cl}=0.32-20.00 ; \mathrm{p}>0.05)$. Moreover, the mean serum $\mathrm{INH}$ concentration in success $(2.46 \pm 0.31 \mu \mathrm{g} / \mathrm{mL})$ and failure $(1.89 \pm 0.20 \mu \mathrm{g} / \mathrm{mL})$ sputum conversion was not significantly different $(p>0.05)$. In conclusion, the acetylation status does not influence the sputum conversion in adult tuberculosis patients after FDC-ATT although the serum INH concentration on slow acetylation status is higher than that fast acetylation status.

\section{ABSTRAK}

Isoniazid (INH) merupakan salah satu obat antituberkulosis utama yang metabolismenya melalui asetilasi. Pada penelitian sebelumnya dilaporkan ada perbedaan kadar INH serum pada orang dengan asetilator cepat dan lambat. Namun demikian hubungan antara status asetilasi dengan keberhasilan terapi penderita tuberkulosis (TB) yang mendapat obat antituberkulosis kombinasi dosis tetap (OAT-KDT) belum dijelaskan secara rinci. Tujuan 
penelitian ini adalah untuk mengkaji pengaruh status asetilasi terhadap keberhasilan terapi dan kadar INH serum penderita TB paru dewasa. Rancangan penelitian adalah potong lintang dengan subjek penelitian sebanyak 31 orang penderita TB. Status asetilasi ditetapkan dengan spektrofotometer dan kadar INH serum dengan high performance liquid chromatography (HPLC). Pemeriksaan sputum dilakukan dengan metode Ziehl Nelsen. Analisis statistik dengan uji t, Chi-square, Mann-Whitney, dan Fisherman. Proporsi status asetilasi cepat sebesar $61,3 \%$ sedangkan asetilator lambat $38,7 \%$. Proporsi keberhasilan konversi sputum 83,9\% dan gagal konversi 16,1\%. Rerata kadar INH serum pada asetilator lambat $(3,84+0,34 \mu \mathrm{g} / \mathrm{mL})$ lebih tinggi secara nyata dibandingkan pada asetilator cepat $(1,52+0,15 \mu \mathrm{g} / \mathrm{mL})(p<0,05)$. Risiko gagal konversi pada kelompok asetilator cepat sekitar 2,53 kali dibandingkan pada asetilator lambat, meskipun tidak bermakna secara nyata $(R R=2,53 ; 95 \% \mathrm{Cl}=0,32-20,00 ; p>0,05)$. Rerata kadar INH serum pada kelompok berhasil konversi yaitu $2,46+0,31 \mu \mathrm{g} / \mathrm{mL}$ tidak berbeda nyata dengan kelompok gagal konversi yaitu $1,89+0,20 \mu \mathrm{g} / \mathrm{mL}(p>0,05)$. Dapat disimpulkan, status asetilasi tidak mempengaruhi konversi sputum pada penderita TB dewasa yang mendapat OAT-KDT meskipun kadar serum INH pada status asetilasi lambat lebih tinggi dari pada status asetilasi cepat.

Keywords: acetylation status - isoniazid level - success of therapy - conversion sputum - intensive phase treatment - tuberculosis

\section{INTRODUCTION}

Tuberculosis (TB) is an infectious disease caused by Mycobacterium tuberculosis ( $M$. tuberculosis). The spread of M. tuberculosis occurs from person to person primarily through droplet transmission in air. ${ }^{1,2}$ Tuberculosis is a major health problem in the world, especially in developing countries. Approximately one third of the world's population has been infected with $M$. tuberculosis with the main source of transmission from TB patients basil hold acid (BTA) positif. ${ }^{3}$

In 2007, World Health Organization (WHO) reported that approximately 9.27 million new cases of TB were reported. This incidence increased from the previous year of 9.24 million new cases in 2006 and 8.3 million new cases in 2000. Mortality due to TB is also reported to be very high. In 2007, 1.3 million deaths from TB or 20 deaths per 100,000 population were reported. Approximately $90 \%$ of the total deaths occur in developing countries. According to WHO, 22 countries are classified as high-burden countries for TB, included Indonesia. ${ }^{4}$

Indonesia ranks third on the list of highburden tuberculosis countries in the world after India and China with the number of TB patients about $10 \%$ of the total number of TB patients in the world. In 2004 there were 539,000 new cases per year and 101,000 deaths occur people from TB in Indonesia. The prevalence rate of smear positive TB in the National was 110 per 100,000 population. ${ }^{3}$ The prevalence of TB in the Yogyakarta and Bali reported the lowest at 68 per 100,000 people. Pulmonary TB disease morbidity in Yogyakarta was 3.18 per 100,000 penduduk. ${ }^{5}$

Tuberculosis become more serious health problem with the increasing of Human Immunodeficiency Virus (HIV)/Acquired Immunodeficiency Syndrome (AIDS) cases. ${ }^{6}$ Another issue that exacerbates tuberculosis is the emergence of multiple drug resistance TB (MDR-TB), which can lead to cases of TB more difficult to treat. ${ }^{7}$ Resistance to antituberculosis mainly due to the inadequateuse use of 
drugs . Inadequate therapy can be caused by inappropriate management therapy. ${ }^{8}$ Since 1995 TB treatment has been carried out using Directly Observed Treatment Shortcourse (DOTS) which is given in two stages, intensive and continuation phases. At the end of the intensive phase and continuation phase, a patient sputum examination is conducted and evaluated. Successful treatment is considered if the patient sputum smear negatif in a microscopic examination is observed. ${ }^{3}$

Isoniazid(INH) is one of the main TB drugs which is generally given in the form of oral antituberculosis (OAT) drug in combination with others. Isoniazid has bacteriostatic and bactericidal activities. The metabolism of INH is affected by a drug metabolizing enzymes in the liver that is $\mathrm{N}$-acetyltransferase 2 (NAT2) through acetylation reaction. Based on the reaction of NAT2 acetylation by this person can be categorized as fast acetylators or lambat. ${ }^{9,10}$

Individuals with rapid acetylator phenotypes must take INH doses greater than those with slow acetylator phenotypes. ${ }^{11}$ Meanwhile another study proved that low serum INH concentrations was observed in individuals with rapid acetylator phenotypes. ${ }^{10}$ The mean blood INH concentration 2 hours after INH administration in individuals with slow acetylator phenotypes was two times higher than those with rapid acetylator phenotypes. ${ }^{12}$ Other studies also reported an association between INH acetylators status with outcome of TB treatment with onceweekly INH and rifapentine. ${ }^{13}$

NAT2 gene polymorphisms that determine the acetylator phenotypes of INH has been known to vary at different race or ethnicity. In the Indonesian population known to $65.4 \%$ of people classified as fast acetylators, and $35.6 \%$ are slow acetylators. ${ }^{14}$ This study was conducted to evaluate the influence of acetylator phenotypes of tuberculosis patients on the serum INH concentration and sputum conversion after intensive phase therapy.

\section{MATERIALS AND METHODS}

This was an observational study using cross sectional design involving 31 subjects who met the inclusion and exclusion criteria. The inclusion criteria were adult patients with pulmonary TB (aged over 18 years) smear positive TB new cases, received TB treatment category 1 (2HRZE / 4H3R3), and willing to participate in the study. The exclusion criteria were subjects with diabetes mellitus, suffer from liver dysfunction, had a history of allergy to sulfa drugs, could not communicate well, not willing to follow the course of TB treatment with DOTS strategy. Protocol of the study was approved by the Medical and Health Research Ethics Committee, Faculty of Medicine, Universitas Gadjah Mada, Yogyakarta.

\section{Protocol of Study}

\section{Acetylation status determination}

The acetylators phenotypes were determined using sulphadimidine according to the method developed by Rao et al. ${ }^{15}$ Patients were given sulphadimidine $500 \mathrm{mg}$ orally early in the morning on empty stomach. They were not allowed to take anything for the next two hours. Urine sample were collected before and 6 hours after sulphadimidine administration. Free and total sulphadimidine in the urine were determined by using spectrophotometer (Spectronic 20D + Thermo Fiher Scientific) at a $\lambda$ of $540 \mathrm{~nm}$. Acetylation status was determined based on the ability to produce the acetylated sulphadimidine (total minus free sulphadimidine) and expressed as a percentage of the total sulphadimidine. Patient was considered as rapid acetylator if 
the acetylated sulphadimidine was $>70 \%$ and as slow acetylator if it was $<70 \%$.

\section{Measurement of serum INH concentration}

Blood sample was taken before (day 0) and at the end of the intensive of treatment (day 56 of treatment). Three mL blood sample was taken from the median cubital vein two hours after OAT administration. The blood sample was then centrifuged at $3000 \mathrm{rpm}$, serum was taken and stored at $-80{ }^{\circ} \mathrm{C}$ until analysed. Serum INH concentration was determined by using High Performance Liquid Chromatography (HPLC) in the Integrated Research and Testing Laboratory, Universitas Gadjah Mada, Yogyakarta. A simple extraction was conducted by protein precipitation with $150 \mu \mathrm{L}$ of trichloroacetic acid $15 \%$ in $300 \mu \mathrm{L}$ serum. The mixture was then vortexed for two min and centrifuged at $3000 \mathrm{rpm}$ for $10 \mathrm{~min}$. The supernatant was collected and $20 \mu \mathrm{L}$ was injected into the HPLC system. The stationary phase was Novapak ${ }^{\circledR}$ C18 column $(150$ x 3.9 $\mathrm{mm}, 3$ microns). The mobile phase consisted of $0.05 \mathrm{M}$ sodium dihydrogen phosphate and acetonitrile (97: 3) and set at a flow rate of $1 \mathrm{~mL} / \mathrm{min}$ at room temperature. The detection was performed at $\lambda$ of $280 \mathrm{~nm}$.

\section{Sputum examination}

Sputum was spread evenly over the central area of the slide which was air dried for about $30 \mathrm{~min}$ and heat fixed. The sputum slide was then flooded with Ziehl Neelsen
(ZN) stain which was then heated to dry, kept for $5 \mathrm{~min}$ and washed with aquadest. The slide was then flooded with $3 \mathrm{~mL}$ of concentrated hydrochloric acid and $97 \mathrm{~mL}$ of ethanol $95 \%$ to decolourise the $\mathrm{ZN}$ stain and washed with aquadest. Thereafter, the slide was flooded with $0.3 \mathrm{~g}$ of methylene blue and $100 \mathrm{~mL}$ of aquadest for $2 \mathrm{~min}$. The slide was air dried at room temperature and viewed on a microscope under oil immersion for presence of acid-fast bacilli. The bacilli were stained red and the background material was stained blue.

\section{Statistical analysis}

Data were presented as mean \pm standard deviation (SD) or percentage and analyzed using SPSS software version 16. Numerical data were compared by using t-test or MannWhitney $U$ test, whereas categorical data were compared by using Chi-square test or Fisher exact test. To determine the relative risk (RR) conversion failures in the rapid and slow acetylators group, $2 \times 2$ table relative risk analysis (Epi Info Program) at the 95\% confidence interval was performed.

\section{RESULTS}

Among 34 subjects who met the inclusion criteria, only 31 patients completed the study. One subject can not be included until the end of the study period due to suffer from liver dysfunction as characterized by high levels of serum transaminases in early therapy and two subjects do not abide taking the drugs. The characteristics of subjects are presented in TABLE 1. 
Anggrain et al., The influence of acetylation status of tuberculosis patients on the isoniazid serum concentrations and sputum conversion after intensive phase therapy

TABLE 1. Patients characteristic $(n=31)$

\begin{tabular}{lc}
\hline \multicolumn{1}{c}{ Characteristic } & Value \\
\hline Age (mean \pm SD year) & $44.2 \pm 13.7$ \\
Sex [n (\%)] & \\
$\quad$ Male & $24(77.4)$ \\
$\quad$ Female & $7(22.6)$ \\
Weight (mean \pm SD kg) & $49.5 \pm 5.8$ \\
Height (mean \pm SD cm) & $164 \pm 6$ \\
Body Mass Index (mean \pm SD) & $18.4 \pm 2.0$ \\
Nutritional Status (\%) & \\
$\quad$ Normal & $13(41.9)$ \\
$\quad$ Low & $18(58.1)$ \\
Smoker [n (\%)] & \\
$\quad$ Yes & $20(64.5)$ \\
$\quad$ No & $11(35.5)$ \\
INH dose [n (\%)] & \\
$225(3$ FDC-ATT) & $24(77.4)$ \\
300 (4 (FDC-ATT) & $7(22.6)$ \\
\hline
\end{tabular}

The proportion of subjects with fast status. Characteristics of patients in the fast or acetylators phenotype status was $61.3 \%$, and $38.7 \%$ was people with slow acetylators slow acetylators did not show any statistically significant difference (TABLE 2).

TABLE 2. Patient characteristics based acetylation status $(n=31)$

\begin{tabular}{lccc}
\hline \multirow{2}{*}{ Characteristics } & \multicolumn{2}{c}{ Acetylation status } & \multirow{2}{*}{ Slow $(\mathrm{n}=12)$} \\
\hline Age (mean \pm SD year) & Fast $(\mathrm{n}=19)$ & \\
Sex (\%) & $42.1 \pm 13.2$ & $45.5 \pm 14.3$ & 0.518 \\
$\quad$ Male & $9(75.0)$ & $15(78.9)$ & \\
$\quad$ Female & $3(25.0)$ & $4(21.1)$ & 1.00 \\
Weight (mean \pm SD kg) & $49.3 \pm 4.9$ & $49.6 \pm 6.5$ & 0.884 \\
Height (mean \pm SD cm) & $165 \pm 7$ & $163 \pm 6$ & 0.251 \\
Body Mass Index $(\mathrm{mean} \pm \mathrm{SD})$ & $18.0 \pm 2.1$ & $18.7 \pm 1.9$ & 0.224 \\
Nutritional Status $(\%)$ & & & \\
$\quad$ Normal & $3(25)$ & $9(47.4)$ & 0.129 \\
$\quad$ Low & $9(75)$ & $10(52.6)$ & \\
Smoker $(\%)$ & & & \\
$\quad$ Yes & $8(66.7)$ & $12(63.2)$ & 0.842 \\
$\quad$ No & $4(33.3)$ & $7(36.8)$ & \\
\hline
\end{tabular}


Most patients had successful sputum conversion (83.9\%), whereas only $16.1 \%$ had failure sputum conversion. Characteristics of patients based on the success and failure of sputum conversion are presented in TABLE 3.

TABLE 3. Patient characteristics based on sputum conversion $(n=31)$

\begin{tabular}{|c|c|c|c|}
\hline \multirow[b]{2}{*}{ Characteristics } & \multicolumn{2}{|c|}{ Acetylation status } & \multirow[b]{2}{*}{$\mathrm{p}$} \\
\hline & $\begin{array}{l}\text { Success } \\
(\mathrm{n}=26)\end{array}$ & $\begin{array}{c}\text { Failure } \\
(\mathrm{n}=5)\end{array}$ & \\
\hline Age (mean \pm SD year) & $42.3 \pm 13.1$ & $54.0 \pm 14.0$ & 0.083 \\
\hline \multicolumn{4}{|l|}{$\operatorname{Sex}[\mathrm{n}(\%)]$} \\
\hline Male & $21(80.8)$ & $3(60.2)$ & \multirow{2}{*}{0.562} \\
\hline Female & $5(19.2)$ & $2(40.0)$ & \\
\hline Weight (mean \pm SD kg) & $49.9 \pm 6.0$ & $47.2 \pm 5.2$ & 0.646 \\
\hline Height (mean $\pm \mathrm{SD} \mathrm{cm}$ ) & $164 \pm 6$ & $161 \pm 6$ & 0.333 \\
\hline Body Mass Index (mean \pm SD) & $17.7 \pm 2.0$ & $18.2 \pm 2.1$ & 0.774 \\
\hline \multicolumn{4}{|l|}{ Nutritional Status [n (\%)] } \\
\hline Normal & $11(42.3)$ & $3(60.0)$ & \multirow{2}{*}{1.000} \\
\hline Low & $15(57.7)$ & $2(40.0)$ & \\
\hline \multicolumn{4}{|l|}{ Smoker [n (\%)] } \\
\hline Yes & $18(69.2)$ & $2(40.0)$ & \multirow{2}{*}{0.317} \\
\hline No & $8(30.8)$ & $3(60.0)$ & \\
\hline \multicolumn{4}{|l|}{ Acetylation status [n (\%)] } \\
\hline Fast & $15(57.7)$ & $4(80)$ & \multirow[t]{2}{*}{0.624} \\
\hline Slow & $11(42.3)$ & $1(20)$ & \\
\hline INH concentration (mean $\pm \mathrm{SEM} \mu \mathrm{g} / \mathrm{mL}$ ) & $22.88 \pm 0.51$ & $1.89 \pm 0.26$ & 0.519 \\
\hline \multicolumn{4}{|l|}{ INH dose $[\mathrm{n}(\%)]$} \\
\hline 225 mg (3 FDC-ATT) & $19(73.1)$ & $5(100)$ & \multirow{2}{*}{0.562} \\
\hline 300 mg (4 FDC-ATT) & $7(26.9)$ & $0(0)$ & \\
\hline
\end{tabular}

Zero in serum INH concentration was observed before treatment begin. After complete treatment (day 56), the mean serum INH concentration was $2.72 \mu \mathrm{g} / \mathrm{mL}$ (ranged from 0.53 to $13.32 \mu \mathrm{g} / \mathrm{mL}$ ). Most individuals who failed sputum conversions (80\%) had a fast acetylators phenotype, whereas in the group succeeded only $57.7 \%$ sputum conversion. But this was not statistically significant (Fisher's exact test, $\mathrm{p}>0.05$ ). Based on the analysis of the $2 \times 2$ table (Epi Info Program) obtained RR $=2.53$ (95\% CI: 0.32 to 20.00). Although the risk of conversion failure in fast acetylators group seen 2 times greater than the slow acetylators, but not statistically significant (TABLE 4). 
Anggrain et al., The influence of acetylation status of tuberculosis patients on the isoniazid serum concentrations and sputum conversion after intensive phase therapy

TABLE 4. Conversion failure risk based on acetylation status $(n=31)$

\begin{tabular}{ccccccc}
\hline \multirow{2}{*}{ Acetylation status } & \multicolumn{2}{c}{ Sputum conversion } & \multirow{2}{*}{ Total } & $\mathrm{x}^{2}, \mathrm{p}$ & $\mathrm{R}$ RR (95\% CI) \\
\cline { 2 - 3 } & \multicolumn{2}{c}{ Success } & Failure & & & \\
\hline Fast & 4 & 15 & 12 & 0.342 & $0.32-20.00$ \\
Slow & 1 & 11 & 19 & & \\
Total & 5 & 26 & & 31 & & \\
\hline
\end{tabular}

The mean serum INH concentration in the slow acetylators patients $(4.63 \mu \mathrm{g} / \mathrm{mL})$ was much higher than fast acetylators $(1.52 \mu \mathrm{g} /$ $\mathrm{mL})$. But in the group of slow acetylators, one subject had extreme INH concentration until $13.32 \mu \mathrm{g} / \mathrm{mL}$. After extreme data excluded, the mean INH concentration of the slow acetylators $(3.84 \pm 0.34 \mu \mathrm{g} / \mathrm{mL})$ was two times higher than that the rapid acetylators $(1.52 \pm 0.15 \mu \mathrm{g} / \mathrm{mL})(\mathrm{p}<0.05)$ as shown on TABLE 5 .

TABLE 5. Serum INH concentration in the fast and slow acetylation status $(n=30)$

\begin{tabular}{ccccccc}
\hline \multirow{2}{*}{ Acetylation status } & \multirow{n}{*}{$\mathrm{n}$} & \multicolumn{5}{c}{ Serum INH concentration $(\mu \mathrm{g} / \mathrm{mL})$} \\
\cline { 3 - 7 } & & Mean & SEM & $95 \%$ CI & Min-Max & $\mathrm{p}$ \\
\hline Fast & 19 & 1.52 & 0.15 & $1.20-1.83$ & $0.53-2.54$ & 0.000 \\
Slow & 11 & 3.84 & 0.34 & $3.07-4.61$ & $2.29-5.01$ & \\
\hline
\end{tabular}

The mean INH concentration in the subjects with failed in sputum conversions $(1.89 \pm 0.20 \mu \mathrm{g} / \mathrm{mL})$ was significantly lower than the subjects with success in sputum conversions $(2.88 \pm 0.51 \mu \mathrm{g} / \mathrm{mL})(\mathrm{p}<0.05)$. One subject with extreme INH concentration was found in the subjects with success in sputum conversion. After subjects with extreme INH concentration excluded, the mean INH concentration between the subjects with success in sputum conversion $(2.46 \pm$ $0.31 \mu \mathrm{g} / \mathrm{mL}$ ) was similar to those with failed in sputum conversion $(1.89 \pm 0.20 \mu \mathrm{g} / \mathrm{mL})$ $(p>0.05)$. 


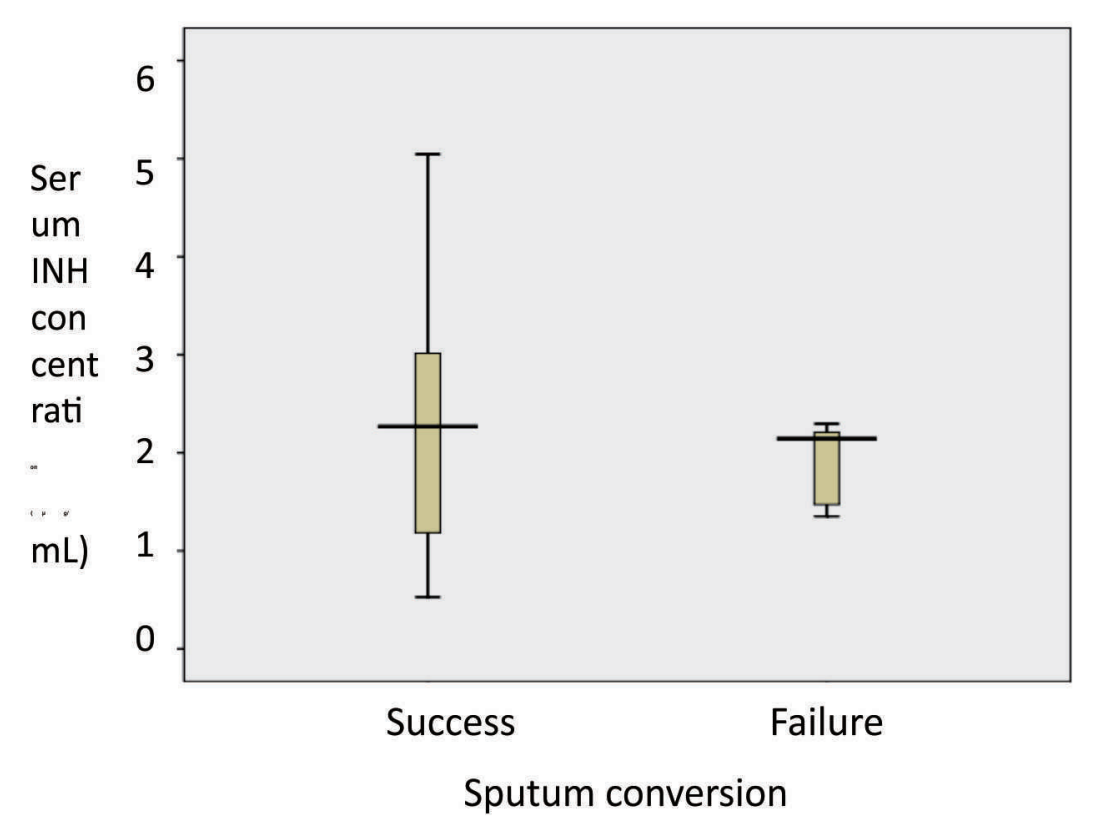

FIGURE 1. Serum INH concentration based on sputum conversion $(n=30)$

Most subjects $(77.4 \%)$ received 3 FDCATT tablets (225 mg INH), and 22.6\% received 4 FDC-ATT tablets $(300 \mathrm{mg})$. The mean serum INH concentration in the group receiving $225 \mathrm{mg}$ or 3 tablets FDC-ATT was no higher than those receiving $300 \mathrm{mg}$ or 4 tablets FDC-ATT $(2.55 \pm 0.30 \mu \mathrm{g} / \mathrm{mL}$ vs. 1.63 $\pm 0.31 \mu \mathrm{g} / \mathrm{mL}$; Mann-Whitney test $\mathrm{p}>0.05$ ) (TABLE 6).

TABLE 6. Serum INH concentration based on INH dose $(n=30)$

\begin{tabular}{lllllll}
\hline Dose of INH & $\mathrm{n}$ & Mean & SEM & $95 \%$ CI & Min-Max & $\mathrm{p}$ \\
\hline $225 \mathrm{mg}$ & 24 & 2.55 & 0.30 & $1.92-3.18$ & $0.59-5.05$ & \\
$300 \mathrm{mg}$ & 6 & 1.63 & 0.31 & $0.83-2.44$ & $0.53-2.67$ & \\
\hline
\end{tabular}

\section{DISCUSSION}

The proportion of rapid acetylation status $(61.3 \%)$ was higher than that slow acetylation status $(38.7 \%)$ in this study. This proportion was similar with the results reported in the previous study conducted in the Community Health Care and Center for Pulmonary Disease Treatment (BP4) in Yogyakarta which found $64 \%$ of patients were rapid acetylation status and $36 \%$ of patients were slow acetylation status. ${ }^{16}$ Furthermore, it was estimated that approximately $2 / 3(66.67 \%)$ of the Indonesian people classified as rapid acetylation status and $1 / 3(33.33 \%)$ as slow acetylation status. ${ }^{14}$

The mean serum INH concentration on 31 patients two hours after drug administration was $2.72 \pm 0.43 \mu \mathrm{g} / \mathrm{mL}$ ranged from 0.53 to $13.32 \mu \mathrm{g} / \mathrm{mL}$ and the median was $2.21 \mu \mathrm{g} /$ 
$\mathrm{mL}$ in this study. Serum INH concentration on TB patients after treatment has been reported in the previous studies. A therapeutic drug monitoring study on TB patients conducted in Virginia, USA reported that the median of serum INH concentration two hours after drugs administration was $1.9 \mu \mathrm{g} / \mathrm{mL}$ (interquartile range 1.1-3.5 $\mu \mathrm{g} / \mathrm{mL}$ ). ${ }^{17}$ Another study conducted on TB patients in Turkey found the mean serum INH concentration two hours after OAT treatment was $3.83 \pm 2.09 \mu \mathrm{g} /$ mL. ${ }^{18}$ Furthermore, study conducted on TB patients in Alberta, Canada found the mean serum INH concentration was $4.13 \pm 3.9 \mu \mathrm{g} /$ mL. ${ }^{19}$

The success of TB treatment is proven by the sputum conversion from smear positive to smear negative at the end of the intensive phase of treatment. In this study TB treatment success rate achieved $83.9 \%$, while the failure rate was $16.1 \%$. The TB treatment success rate has been reported from various regions. The Province Health Office in Yogyakarta Special Region reported that the TB treatment success rate achieved $87 \% .{ }^{20} \mathrm{~A}$ study conducted in UK demonstrated the TB treatment success rate was $87 . \%{ }^{21}$ However, in 2013 in America and European regions the TB treatment success rate was $75 \%$, whereas in Malaysia was $67 \%$ less than the $85 \%$ success target set by the WHO. Globally, the TB treatment success rate for people newly diagnosed with TB was $86 \%$ in $2013 .^{22,23}$

The TB treatment failure on the rapid acetylator group ( $80 \%$ or 4 people) was higher compared to on the slow acetylation status group ( $20 \%$ or 1 people). The RR of failure in the sputum conversion of fast acetylation status group was two times higher than the slow acetylation status group although it was not significantly different. This results is different from the previous study that showed a relationship between acetylation status and outcome of TB treatment with once-weekly INH and rifapentine. ${ }^{13}$ The different of dosage regimen and patient compliance may cause the different of these results.

The mean serum INH concentration of slow acetylation status group $(3.84 \pm 0.34 \mu \mathrm{g} /$ $\mathrm{mL}$ ) was higher than that rapid acetylation status $(1.52 \pm 0.15 \mu \mathrm{g} / \mathrm{mL})$. The higher serum INH concentration of slow acetylation status compared to that rapid acetylation status was also reported in the previous studies. Schaaf et al. ${ }^{12}$ reported the serum INH concentration of slow acetylation status $(8.6 \mu \mathrm{g} / \mathrm{mL})$ was twoold higher than that rapid acetylation status (3.94 $\mu \mathrm{g} / \mathrm{mL})$. Furthermore, Conte et al. ${ }^{24}$ also reported the serum INH concentration of slow acetylation status $(1.1 \pm 0.8 \mu \mathrm{g} / \mathrm{mL})$ was higher than that rapid acetylation status $(0.5 \pm$ $0.6 \mu \mathrm{g} / \mathrm{mL})$.

The mean serum INH concentration in the patients with failed in sputum conversions $(1.89 \pm 0.20 \mu \mathrm{g} / \mathrm{mL})$ was significantly lower than the subjects with success in sputum conversions $(2.46 \pm 0.31 \mu \mathrm{g} / \mathrm{mL})$. However, it was not significantly different $(\mathrm{p}>0.05)$. It was reported that effective of tuberculostatic minimal concentration of INH range from 0.025 to $0.05 \mu \mathrm{g} / \mathrm{mL}$, whereas the therapeutic INH concentration range from 0.5 to $2.0 \mu \mathrm{g} /$ $\mathrm{mL}{ }^{25-27}$ In this study, the mean serum INH concentration in the both patients with filed and success in sputum conversions met the therapeutic INH concentration that indicated serum INH concentration did not influence the sputum conversion. No different in serum INH concentration in the patients with failed and success in sputum conversions nor in the patients with delays and avoid delay in sputum conversions were also reported in the previous study. ${ }^{25}$ 


\section{CONCLUSIONS}

Adult pulmonary TB patient with rapid acetylation status has lower serum INH concentrations than slow acetylation status. However, these serum INH concentrations are still within the therapeutic INH concentration therefore the acetylation status does not affect the sputum conversion after the intensive phase of TB treatment.

\section{ACKNOWLEDGEMENTS}

We would like to thank all subjects who participated in this study.

\section{REFERENCES}

1. Raviglione MC \& O'Brien RJ. Tuberculosis. In: AS Fauci, DL Kasper, DL Longo, E Braunwald, SL Hauser, JL Lameson, J Loscalzo, editors. Harrison's Principles of Internal Medicine. $17^{\text {th }}$ edition. New York: Mc.Graw Hill Companies Inc, 2008: 100620.

2. Lo Bue PA, Ademarco MF, Casatro KG. The epidemiology, prevention, and control of tuberculosis in the United States. In: AP Fishman, JA Elias, MA Grippi, RM Senior, and AI Pack, editors. Fishman's Pulmonary Diseases and Disorders. Fourth edition. San Fransisco: Mc.Graw Hill Companies Inc, 2008: 2446-57.

3. DepkesRI.Pedomannasional penanggulangan tuberkulosis. Edisi 2, cetakan pertama. Jakarta: Departemen Kesehatan RI, 2007.

4. World Health Organization. World Health Organization report 2009: Global tuberculosis control epidemiology, strategy, financing. Geneva: World Health Organization, 2009.

5. Dinas Kesehatan Provinsi DI Yogyakarta. Profil kesehatan Propinsi DI Yogyakarta tahun 2008. Yogyakarta: Dinas Kesehatan Provinsi D I Yogyakarta, 2008.
6. Swaminathan S, Narendran G. HIV and tuberculosis in India. J Biosci 2008; 33: $527-$ 37.

http://dx.doi.org/10.1007/s12038-008-0071-2

7. Aditama, TY. XDR-TB. JTI 2006; 3(2):20-2.

8. Rintiswati N, Dwianingsih EK, Rahman A, Iswanto, Rizal Y, Sumardi. Resistensi Mycobacterium tuberculosis terhadap beberapa obat anti tuberculosis pilihan utama dan pilihan kedua di Laboratorium Mikrobiologi FK UGM tahun 2000-2004. BIK 2005; 37(4):190-7.

9. Kinzig-Schippers M, Tomalik-Scharte D, Jetter A, Scheidel B, Jakob V, Rodamer M, et al. Should we use N-Acetyltransferase type 2 genotyping to personalize isoniazid doses? Antimicrob Agents Chemother 2005; 49: 1733-8.

http://dx.doi.org/10.1128/AAC.49.5.17331738.2005

10. Fukino K, Sasaki Y, Hirai S, Nakamura T, Hashimoto M, Yamagishi F, et al. Effects of N-acetyltransferase 2 (NAT2), CYP2E1 and Glutathione-S-transferase (GST) genotypes on the serum concentrations of isoniazid and metabolites in tuberculosis patients. J Toxicol Sci 2008; 33(2):187-95. http://dx.doi.org/10.2131/jts.33.187

11. Ellard GA. Variations between individuals and populations in the acetylation of isoniazid and its significance for the treatment of pulmonary tuberculosis. Clin Pharmacol Ther 1976;19: 610-25.

ht tp://dx.doi.org/10.1002/ cpt1976195part2610

12. Schaaf HS, Parkin DP, Seifart HI, Werely CJ, Hesseling PB, van Helden PD, et al. Isoniazid pharmacokinetics in children treated for respiratory tuberculosis. Arch Dis Child 2005; 90: 614-8. http://dx.doi.org/10.1136/adc.2004.052175

13. Weiner M, Burman W, Vernon A, Benator D, Peloquin CA, Khan A, et al. Low isoniazid 
concentrations and outcome of tuberculosis treatment with once-weekly isoniazid and rifapentine. Am J Respir Crit Care Med 2003; 167: $1341-7$.

http://dx.doi.org/10.1164/rcem.2002089510C

14. Yuliwulandari R, Sachrowardi Q, Nishida N, Takasu M, Batubara L, Susmiarsih TP, et al. Polymorphisms of promoter and coding regions of the arylamine $N$-acetyltransferase 2 (NAT2) gene in the Indonesian population: proposal for a new nomenclature. J Hum Genetics 2008; 53: 201-9. http://dx.doi.org/10.1007/s10038-007-0237-z

15. Rao KVN, Mitchison DA, Nair NGK, Prema K, Tripathy SP. Sulphadimidine acetylation test for classification of patients as slow or rapid acetylators of isoniazid. Br Med J 1970; 3: 495497.

http://dx.doi.org/10.1136/bmj.3.5721.495

16. Santoso B, Sugiyanto, Asdie S, Effendi R. Absence of relationship between isoniazidinduced hepatic disturbances and acetylator phenotype. BKM 1991; 7 (3): 169-78.

17. Heysell SK, Moore JL, Keller SJ, Houpt ER. Therapeutic Drug Monitoring for slow response to tuberculosis treatment in a state control program, Virginia, USA. Emerg Infect Dis 2010; 16(10): 1546-53. http://dx.doi.org/10.3201/eid1610.100374

18. Kayhan S \& Akgunes A. Therapeutic monitoring of isoniazid, rifampicin, ethambutol and pyrazinamide serum levels in the treatment of active pulmonary tuberculosis and determinants of their serum concentrations. African J Pharm Pharmacol 2011; 5(17): 2035-41.

http://dx.doi.org/10.5897/AJPP11.511

19. Mah A, Kharrat H, Ahmed R, Gao Z, Der E, Hansen E, et al. Serum drug concentrations of INH and RMP predict 2-month sputum culture results in tuberculosis patients. Int $\mathrm{J}$ Tuberc Lung Dis 2015; 19(2):2010-15. http://dx.doi.org/10.5588/ijtld.14.0405
20. Dinas Kesehatan Provinsi DI Yogyakarta. Profil kesehatan Provinsi DI Yogyakarta 2008. Yogyakarta: Dinas Kesehatan Provinsi DI Yogyakarta, 2008.

21. Ditah IC, Reacher M, Palmer C, Watson JM, Innes J, Kruijshaar ME, et al. Monitoring tuberculosis treatment outcome: analysis of national surveillance data from a clinical perspective. Thorax 2008; 63:440-6. http://dx.doi.org/10.1136/thx.2006.073916

22. World Health Organization. Global tuberculosis report 2015. Geneva: World Health Organization, 2015.

23. Atif M, Sulaiman SAS, Shafie AA, Ali I, Asif M, Babar ZUD. Treatment outcome of new smear positive pulmonary tuberculosis patients in Penang, Malaysia. BMC Infect Dis 2014; 14:399. http://dx.doi.org/10.1186/1471-2334-14-399

24. Conte JE, Golden, JA, McQuitty M, Kipps J, Duncan S, McKenna E et al. Effects of gender, AIDS, and acetylator status on intrapulmonary concentrations of isoniazid. Antimicrob Agents Chemother 2002; 46 (8):2358-64.

http://dx.doi.org/10.1128/AAC.46.8.23582364.2002

25. Petri WA. Chemotherapy of tuberculosis, Mycobacterium avium complex disease, and leprosy. In: L Brunton, J Lazo, and KL Parker, eds. Goodman and Gilman's the Pharmacological Basic of Therapeutics. 11 $1^{\text {th }}$ edition. New York: Mc. Graw Hill Companies Inc, 2006; 1203-23.

26. Roy V, Tekur U, Chopra K. Pharmacokinetics of isoniazid in pulmonary tuberculosis-a comparative study at two dose levels. Ind Pediatrics 1996;33:287-92.

27. Tappero JW, Bradford WZ, Agerton TB, Hopewell P, Reingold AL, Lockman S, et al. Serum concentration of antimycobacterial drugs in patients with pulmonary tuberculosis in Botswana. Clin Inf Dis 2005; 41: 461-9. http://dx.doi.org/10.1086/431984. 